\title{
PERAN KEPUASAN KERJA MEMEDIASI PENGARUH STRES KERJA TERHADAP KOMITMEN ORGANISASIONAL
}

\author{
Putu Rizky Maysa Wirawan ${ }^{1}$ \\ AA. Sagung Kartika Dewi \\ ${ }^{1,2}$ Fakultas Ekonomi dan Bisnis Universitas Udayana (Unud), Bali, Indonesia \\ email: riskymaysa13@gmail.com
}

\begin{abstract}
ABSTRAK
Tujuan penelitian ini adalah untuk menganalisis pengaruh stress kerja terhadap kepuasan kerja, untuk menganalisis pengaruh kepuasan kerja terhadap komitmen organisasi, untuk menganalisis pengaruh stres kerja terhadap komitmen organisasi untuk menganalisis kepuasan kerja dalam mediasi pengaruh stres kerja terhadap komitmen. Penelitian ini dilakukan pada UPT. Monumen Perjuangan Rakyat Bali. Jumlah sampel yang digunakan dalam penelitian ini yaitu 49 pegawai, dengan menggunakan metode sampel jenuh (sensus), dimana menggunakan keseluruhan populasi sebagai sampel. Data di analisis menggunakan teknik analisis jalur (Path Analysis). Hasil penelitian menunjukkan bahwa stres kerja berpengaruh negatif dan signifikan terhadap kepuasan kerja pada UPT. Monumen Perjuangan Rakyat Bali, kepuasan kerja berpengaruh positif dan signifikan terhadap komitmen organisasional, stres kerja berpengaruh negative dan signifikan terhadap komitmen organisasional, serta kepuasan kerja Memediasi Pengaruh Stres Kerja terhadap Komitmen Organisasional pada UPT. Monumen Perjuangan Rakyat Bali.

Kata Kunci: stres kerja, kepuasan kerja, komitmen organisasional
\end{abstract}

\begin{abstract}
The purpose of this study was to analyze the effect of work stress on job satisfaction, to analyze the effect of job satisfaction on organizational commitment, to analyze the effect of work stress on organizational commitment to analyze job satisfaction in mediating the effect of work stress on commitment. This research was conducted at the UPT. Monument to the Struggle of the People of Bali. The number of samples used in this study is 49 employees, using the saturated sample method (census), which uses the entire population as a sample. Data analyzed using Path Analysis techniques. The results showed that work stress had a negative and significant effect on job satisfaction at the UPT. Monumen Perjuangan Rakyat Bali, job satisfaction has a positive and significant effect on organizational commitment, work stress has a negative and significant effect on organizational commitment, and job satisfaction Mediates the Effects of Job Stress on Organizational Commitments on UPT. Monument to the Struggle of the People of Bali. Keywords: work stress, job satisfaction, organizational commitment
\end{abstract}




\section{PENDAHULUAN}

Karyawan merupakan sumber daya yang berguna dalam keberhasilan suatu organisasi. Kegagalan seorang karyawan dalam melaksanakan tugas dan tanggung jawabnya akan memengaruhi proses pencapaian tujuan yang telah ditetapkan organisasi. Maka seorang atasan harus memperhatikan karyawannya yang mengalami kegagalan dalam melaksakan tugas dan tanggung jawabnya (Hassan, 2002)

Komitmen organisasional adalah suatu keadaan seorang karyawan untuk mempertahankan keanggotaan dalam organisasi dengan memihak organisasi serta tujuan dan keinginannya (Irawati \& Liana, 2013). (Putri et al., 2014) menyatakan semua organisasi wajib memiliki komitmen organisasi yang tinggi dari para karyawan sehingga mampu mencapai tujuan bersama organisasi dan tujuan individu. (Murty \& Hudiwinarsih, 2012), karyawan yang memiliki komitmen organisasional adalah karyawan yang mampu mengidentifikasi keterlibatan dirinya dalam organisasi.

(Karwati \& Priansa, 2014) komitmen organisasional merupakan identifikasi rasa, keterlibatan, dan loyalitas yang ditampakkan oleh karyawan terhadap organisasi yang menjadi tempatnya untuk mengabdi dan bekerja. (Karim \& Rehman, 2012) mengatakan komitmen organisasi sebagai keyakinan teguh dalam pengakuan dari karyawan mengenai tujuan atau prinsip-prinsip organisasi, dan memiliki keyakinan besar atas organisasi dan ingin tetep ada serta bertahan didalam organisasi. Komitmen yang tinggi dari para seluruh anggota organisasi sangat dibutuhkan agar tujuan-tujuan individu maupun tujuan organisasi dapat terwujud (Putri et al., 2014).

Rendahnya tingkat komitmen organisasional juga dapat di pengaruhi oleh stres kerja yang dialami, stres yang dialami anggota organisasi perlu diperhatikan untuk mengetahui pengaruhnya terhadap intensitas komitmen (Khatibi et al., 2009). Sejalan dengan temuan (Harun et al., 2017) yang menunjukkan bahwa komitmen organisasional juga dipengaruhi oleh stres kerja, karyawan yang mendapatkan tingkat stres yang tinggi akan menyebabkan rendahnya komitmen organisasional. Prediktor rendahnya komitmen organisasional berdasarkan kajian terhadap penelitian sebelumnya dipengaruhi oleh stres kerja yang tinggi (Rismawan et al., 2014).

Stres kerja adalah sesuatu mengenai lingkungan kerja atau sifat pekerjaan itu sendiri yang menyebabkan stres yang dirasakan oleh individu (Bokti \& Talib, 2009). Stres didefinisikan sebagai"suatu situasi dimana akan memaksa seseorang untuk melakukan penyimpangan dari fungsi normal" dikarenakan perubahan yang mengganggu atau meningkatkan kondisi fisiologis dan psikologis, sehingga seseorang tersebut dipaksa untuk menyimpang darifungsi normal (Karim \& Rehman, 2012). (Luthans, 2008) mendefenisikan stres sebagai suatu tanggapan dalam menyesuaikan diri yang dipengaruhi oleh perbedaan individu dan proses psikologi, sebagai konsekuensi dari tindakan lingkungan, situasi atau peristiwa yang terlalu banyak mengadakan tuntutan psikologis dan fisik seseorang.

Stres merupakan isu utama yang menjadi perhatian karena telah menjadi bagian dari kehidupan karyawan dan sulit untuk menghindari stres dari pekerjaan (Parvaiz et al., 2015). Stres merupakan sebuah kondisi dimana seseorang 
dihadapkan pada konfrontasi antara kesempatan, hambatan, atau permintaan akan apa yang dia inginkan dan hasilnya dipersepsikan tidak pasti dan penting (Noviansyah \& Zunaidah, 2011). Menurut (Jamal, 2011), stres kerja merupakan karakteristik lingkungan kerja yang dirasa mengancam secara emosi dan fisik oleh karyawan.

(Afrizal et al., 2014) menunjukkan bahwa stres kerja berpengaruh negatif dan signifikan terhadap kepuasan kerja. (Umar, 2014) menyatakan bahwa stres mempunyai potensi untuk mengganggu kepuasan kerja karyawan, tergantung dari berapa besar tingkat stress. Stres kerja pada karyawan sebagai salah satu akibat dari bekerja yang perlu dikondisikan pada posisi yang tepat agar kepuasan kerja karyawan juga pada posisi yang diharapkan karena stres kerja mempunyai potensi yang sangat besar untuk menggangu kepuasan kerja karyawan (Umar, 2014).

Menurut (Özer \& Günlük, 2010) kepuasan kerja adalah salah satu komponen penting dari karyawan, dan sikap yang mungkin akan berpengaruh terhadap apa yang karyawan tersebut rasakan. (Ali, 2009) menyatakan kepuasan kerja merupakan salah satu faktor yang sangat penting untuk mendapatkan hasil kerja yang optimal. (Sutrisno, 2016), kepuasan kerja adalah perasaan senang atau bahagia seorang pekerja dalam menghormati dan melaksanakan pekerjaannya.

Kepuasan kerja merupaka $\mathrm{n}$ keadaan emosional yang menyenangkan atau tidak menyenangkan ketika para karyawan memandang pekerjaan mereka (Handoko, 2012). Pada dasarnya kepuasan kerja merupakan hal yang bersifat individual karena tiap individu memiliki tingkat kepuasan yang berbeda-beda dengan sistem nilai yang berlaku pada dirinya (Priyono, 2012). Penelitian yang dilakukan oleh (Raharjo \& Nafisah, 2006) menyatakan kepuasan kerja sangat penting karena merupakan dampak atau hasil dari keefektifan performance dan kesuksessan dalam bekerja.

(Pangat, 2013) melihat bahwa faktor lain yang mempengaruhi komitmen organisasi adalah menciptakan kepuasan kerja yang konsisten bagi karyawan, dengan selalu memberi perhatian lebih terhadap lingkungan dimana karyawan tersebut melaksanakan tugasnya yang berhubungan dengan rekan kerja, pemimpin, suasana kerja dan hal lain yang dapat mempengaruhi kemampuan seseorang dalam menjalankan pekerjaannya. Individu yang merasa puas dengan pekerjaannya akan memiliki komitmen yang tinggi terhadap perusahaan dan keinginan untuk meninggalkan perusahaan akan semakin rendah (Iqbal et al., 2014). Kepuasan kerja merupakan aspek pertama yang dicapai sebelum seorang karyawan memiliki komitmen organisasional (Taurisa, 2012).

Hasil penelitian dari (Christama, 2011) menunjukan bahwa kepuasan kerja mampu memediasi peran stres kerja terhadap komitmen organisasi pada caddy PT. Golf Graha Family Surabaya. Selain itu, menurut (Kasanah, 2007), menunjukkan ada pengaruh positif secara tidak langsung yang signifikan antara stres terkait tantangan dengan komitmen organisasi melalui kepuasan kerja.

Museum Perjuangan Rakyat Bali (Bajra Sandhi) tercetus pada tahun 1980 yang berawal dari ide Prof. Dr. Ida Bagus Mantra yang saat itu adalah Gubernur Bali, dan akhirnya pada tanggal 1 Agustus 2004 pelayanan kepada masyarakat dibuka secara umum. Monumen ini terletak di kawasan Lapangan Renon, tepatnya di jalan Niti Mandala Renon. Museum ini menjadi simbol masyarakat 
Bali untuk menghormati para pahlawan serta merupakan lambang persemaian pelestarian jiwa perjuangan rakyat Bali dari generasi ke generasi dan dari zaman ke zaman, serta lambang semangat untuk mempertahankan keutuhan Negara Kesatuan Republik Indonesia. Upaya meningkatkan mutu pelayanan Unit Pelayanan Terpadu (UPT) Monumen Perjuangan Rakyat Bali di tuntut untuk lebih professional dalam upaya pemberian pelayanan. Mutu pelayanan yang baik, perusahaan harus didukung dengan memiliki karyawan dengan tingkat disiplin yang tinggi agar dapat mencapai tujuan organisasi dengan adanya sumber daya manusia yang berkualitas.

Jumlah pegawai yang dimiliki oleh UPT. Monumen Perjuangan Rakyat Bali dapat dilihat pada Tabel 1 .

Tabel 1.

Data Pegawai UPT. Monumen Perjuangan Rakyat Bali 2018

\begin{tabular}{clc}
\hline No & \multicolumn{1}{c}{ Bagian } & $\begin{array}{c}\text { Jumlah Karyawan } \\
\text { (Orang) }\end{array}$ \\
\hline 1 & Kepala UPT. & 1 \\
2 & KASUBAG. TU. & 1 \\
3 & KASI. Informasi & 1 \\
4 & KASI. Penelitian & 1 \\
5 & Staf Bagian TU & 15 \\
6 & Staf Bagian Informasi & 12 \\
7 & Staf Bagian Penelitian & 9 \\
8 & Tenaga Keamanan & 9 \\
& Total & 49 \\
\hline
\end{tabular}

Sumber: Tata Usaha UPT Monumen Perjuangan Rakyat Bali, 2019

Berdasarkan hasil prariset kepada 10 orang pegawai pada UPT. Monumen Perjuangan Rakyat Bali, 2 orang pegawai dari bagian tata usaha dan informasi menyatakan tidak setuju dengan pernyataan "saya merasa ikut memiliki perusahaan" hal ini berkaitan dengan rendahnya komitmen organisasional dialami oleh pegawai, seperti kurangnya tingkat ketidak disiplinan pegawai pada saat jam kerja berlangsung, contohnya masih banyaknya pegawai yang berkomunikasi diluar urusan pekerjan dengan rekan kerja ketika jam kerja sehingga banyak pekerjaan yang belum terselesaikan, masih terdapat pegawai yang menyelesaikan suatu pekerjaan jika atasan sudah meminta hasil pekerjaan tersebut sehingga dikerjakan dalam keadaan mendesak yang menyebabkan hasilnya menjadi kurang maksimal. Berdasarkan hasil prariset permasalahan ini terjadi karena masih adanya pegawai yang kurang memiliki tanggung jawab dalam melaksanakan tugas, contohnya sebagian pegawai cenderung kurang bermotivasi dalam bekerja, dan komunikasi yang tidak baik antara pegawai satu dengan yang lainnya yang dapat menimbulkan perbedaan pendapatan diantara para pegawai.

Berdasarkan uraian yang telah dijelaskan diatas menunjukkan adanya pengaruh secara langsung maupun tidak langsung dari stress kerja terhadap komitmen organisasional. Penelitian ini ingin mengetahui bagaimana pengaruh stres kerja terhadap komitmen organisasional, baik secara langsung maupun tidak langsung melalui kepuasan kerja pada UPT. Monumen Perjuangan Rakyat Bali Penelitian ini dilakukan pada UPT. Monumen Perjuangan Rakyat Bali karena adanya masalah komitmen organisasional pada karyawan. 
Stres kerja berpengaruh negatif terhadap kepuasan kerja karyawan. Hal ini menunjukkan bahwa semakin tinggi stress kerja yang dirasakan oleh karyawan, maka kepuasan kerja karyawan akan menurun atau sebaliknya, semakin rendah stress kerja maka semakin tinggi kepuasan kerja karyawan (Fadhilah, 2010). Stres kerja memiliki pengaruh negatif yang signifikan terhadap kepuasan kerja, hal ini bermakna stres kerja yang dialami karyawan dapat mempengaruhi apa yang mereka rasakan baik itu menyangkut pekerjaan maupun hasil yang mereka terima (Wibowo et al., 2015). (Dewi \& Netra, 2015) Stres kerja terhadap kepuasan kerja berpengaruh negatif dan signifikan sesuai dengan pendapat (Tukimin, 2014), (Li et al., 2014) berpendapat bahwa pengaruh stress kerja terhadap kepuasan kerja berpengaruh negatif dikarenakan adanya pengembangan karir, stres upah dan imbalan yang menjadi faktor. Di dukung dari penelitian sebelumnya yang dilakukan oleh (Dhania, 2010), menyatakan bahwa stress kerja mempunyai pengaruh negatif dan signifikan terhadap kepuasan kerja. (Chaudhry, 2012), menyatakan bahwa terdapat pengaruh yang negatif dan signifikan antara stress kerja dengan kepuasan kerja

$\mathrm{H}_{1}$ : Stres kerja berpengaruh negative dan signifikan terhadap kepuasan kerja

(Kartikarini, 2015) mengatakan bahwa kepuasan kerja memiliki keterkaitan positif terhadap komitmen organisasi. Begitu juga dengan (Eslami \& Gharakhani, 2012) yang menyatakan karyawan yang memiliki kepuasan kerja cenderung berkomitmen untuk organisasi dan karyawan yang puas dan berkomitmen lebih mungkin untuk menghadiri pekerjaan. (Lumley et al., 2011) menyimpulkan kepuasan kerja mempengaruhi sikap masyarakat terhadap pekerjaan dan berbagai aspek pekerjaan mereka, kepuasan kerja dipengaruhi oleh pribadi yang menyebabkan reaksi emosional yang mempengaruhi komitmen organisasi. Sebelum memiliki komitmen organisasional seorang karyawan haruslah merasa puas dalam pekerjaannya dimana menurut (Gunlu et al., 2010) kepuasan kerja memiliki pengaruh yang signifikan terhadap komitmen organisasional. (Yani et al., 2016), mengatakan bahwa kepuasan kerja berpengaruh positif dan signifikan terhadap komitmen organisasional.

$\mathrm{H}_{2}$ : Kepuasan Kerja berpengaruh positif dan signifikan terhadap komitmen organisasional

(Khatibi et al., 2009) menyatakan ada hubungan negatif antara stres kerja dengan komitmen organisasi, pegawai yang memiliki tingkat stres tinggi berimplikasi terhadap rendahnya komitmen organisasi mereka. Begitu juga dengan (Velnampy \& Aravinthan, 2013) yang menyatakan adanya hubungan negatif antara stres kerja dan komitmen organisasi. Stres kerja berpengaruh negatif pada komitmen organisasi karena semakin tinggi stres mengakibatkan semakin menurunnya komitmen organisasi (Iresa et al., 2015). Penelitian yang dilakukan (Cha et al., 2016) dalam penelitiannya mengungkapkan stres kerja memiliki hubungan yang negatif dan signifikan dengan komitmen organisasional. Penelitian (Harun et al., 2017) menunjukkan stres kerja memiliki hubungan negatif yang signifikan dengan komitmen organisasi.

$\mathrm{H}_{3}$ : Stres kerja berpengaruh negative dan signifikan terhadap komitmen organisasional 
Hasil penelitian dari (Christama, 2011), menunjukan bahwa kepuasan kerja mampu memediasi peran stres kerja terhadap komitmen organisasi pada caddy PT. Golf Graha Family Surabaya. Selain itu, menurut (Kasanah, 2007), menunjukkan ada pengaruh positif secara tidak langsung yang signifikan antara stres terkait tantangan dengan komitmen organisasi melalui kepuasan kerja. (Yousef, 2002), menyatakan bahwa terdapat hubungan yang signifikan antara kepuasan kerja dan komitmen organisasional yang dapat memperkuat pengaruh antara stress kerja terhadap komitmen organisasional. Menurut (Soejipto, 2008), menyatakan kepuasan kerja pemediasi pengaruh stress kerja terhadap komitmen organisasiona pada PT. Octa Mitranusa dengan hasil penelitian terdapat pengaruh negative signifikan stress kerja terhadap komitmen organisasional dengan kepuasan kerja sebagai variable mediasi. Kepuasan mampu memediasi pengaruh antara stress kerja terhadap komitmen organisasional (Sepa, 2013).

$\mathrm{H}_{4}$ : Kepuasan kerja Memediasi Pengaruh Stres Kerja terhadap Komitmen Organisasional

Rendahnya tingkat komitmen organisasional juga dapat di pengaruhi oleh stres kerja yang dialami, stres yang dialami anggota organisasi perlu diperhatikan untuk mengetahui pengaruhnya terhadap intensitas komitmen (Khatibi et al., 2009). Sejalan dengan temuan (Harun et al., 2017) yang menunjukkan bahwa komitmen organisasional juga dipengaruhi oleh stres kerja, karyawan yang mendapatkan tingkat stres yang tinggi akan menyebabkan rendahnya komitmen organisasional. Prediktor rendahnya komitmen organisasional berdasarkan kajian terhadap penelitian sebelumnya dipengaruhi oleh stres kerja yang tinggi (Rismawan et al., 2014).

Stres kerja adalah sesuatu mengenai lingkungan kerja atau sifat pekerjaan itu sendiri yang menyebabkan stres yang dirasakan oleh individu (Bokti \& Talib, 2009). Stres didefinisikan sebagai"suatu situasi dimana akan memaksa seseorang untuk melakukan penyimpangan dari fungsi normal" dikarenakan perubahan yang mengganggu atau meningkatkan kondisi fisiologis dan psikologis, sehingga seseorang tersebut dipaksa untuk menyimpang darifungsi normal (Karim \& Rehman, 2012). (Luthans, 2008) mendefenisikan stres sebagai suatu tanggapan dalam menyesuaikan diri yang dipengaruhi oleh perbedaan individu dan proses psikologi, sebagai konsekuensi dari tindakan lingkungan, situasi atau peristiwa yang terlalu banyak mengadakan tuntutan psikologis dan fisik seseorang.

Stres merupakan isu utama yang menjadi perhatian karena telah menjadi bagian dari kehidupan karyawan dan sulit untuk menghindari stres dari pekerjaan (Parvaiz et al., 2015). Stres merupakan sebuah kondisi dimana seseorang dihadapkan pada konfrontasi antara kesempatan, hambatan, atau permintaan akan apa yang dia inginkan dan hasilnya dipersepsikan tidak pasti dan penting (Noviansyah \& Zunaidah, 2011). Menurut (Jamal, 2011), stres kerja merupakan karakteristik lingkungan kerja yang dirasa mengancam secara emosi dan fisik oleh karyawan.

(Afrizal et al., 2014) menunjukkan bahwa stres kerja berpengaruh negatif dan signifikan terhadap kepuasan kerja. (Umar, 2014) menyatakan bahwa stres mempunyai potensi untuk mengganggu kepuasan kerja karyawan, tergantung dari berapa besar tingkat stress. Stres kerja pada karyawan sebagai salah satu akibat 
dari bekerja yang perlu dikondisikan pada posisi yang tepat agar kepuasan kerja karyawan juga pada posisi yang diharapkan karena stres kerja mempunyai potensi yang sangat besar untuk menggangu kepuasan kerja karyawan (Umar, 2014).

Komitmen organisasional adalah suatu keadaan seorang karyawan untuk mempertahankan keanggotaan dalam organisasi dengan memihak organisasi serta tujuan dan keinginannya (Irawati \& Liana, 2013). (Putri et al., 2014) menyatakan semua organisasi wajib memiliki komitmen organisasi yang tinggi dari para karyawan sehingga mampu mencapai tujuan bersama organisasi dan tujuan individu. (Murty \& Hudiwinarsih, 2012), karyawan yang memiliki komitmen organisasional adalah karyawan yang mampu mengidentifikasi keterlibatan dirinya dalam organisasi.

(Karwati \& Priansa, 2014) komitmen organisasional merupakan identifikasi rasa, keterlibatan, dan loyalitas yang ditampakkan oleh karyawan terhadap organisasi yang menjadi tempatnya untuk mengabdi dan bekerja. (Karim \& Rehman, 2012) mengatakan komitmen organisasi sebagai keyakinan teguh dalam pengakuan dari karyawan mengenai tujuan atau prinsip-prinsip organisasi, dan memiliki keyakinan besar atas organisasi dan ingin tetep ada serta bertahan didalam organisasi. Komitmen yang tinggi dari para seluruh anggota organisasi sangat dibutuhkan agar tujuan-tujuan individu maupun tujuan organisasi dapat terwujud (Putri et al., 2014).

Rendahnya tingkat komitmen organisasional juga dapat di pengaruhi oleh stres kerja yang dialami, stres yang dialami anggota organisasi perlu diperhatikan untuk mengetahui pengaruhnya terhadap intensitas komitmen (Khatibi et al., 2009). Sejalan dengan temuan (Harun et al., 2017) yang menunjukkan bahwa komitmen organisasional juga dipengaruhi oleh stres kerja, karyawan yang mendapatkan tingkat stres yang tinggi akan menyebabkan rendahnya komitmen organisasional. Prediktor rendahnya komitmen organisasional berdasarkan kajian terhadap penelitian sebelumnya dipengaruhi oleh stres kerja yang tinggi (Rismawan et al., 2014).

Stres kerja adalah sesuatu mengenai lingkungan kerja atau sifat pekerjaan itu sendiri yang menyebabkan stres yang dirasakan oleh individu (Bokti \& Talib, 2009). Stres didefinisikan sebagai"suatu situasi dimana akan memaksa seseorang untuk melakukan penyimpangan dari fungsi normal" dikarenakan perubahan yang mengganggu atau meningkatkan kondisi fisiologis dan psikologis, sehingga seseorang tersebut dipaksa untuk menyimpang darifungsi normal (Karim \& Rehman, 2012). (Luthans, 2008) mendefenisikan stres sebagai suatu tanggapan dalam menyesuaikan diri yang dipengaruhi oleh perbedaan individu dan proses psikologi, sebagai konsekuensi dari tindakan lingkungan, situasi atau peristiwa yang terlalu banyak mengadakan tuntutan psikologis dan fisik seseorang.

Stres merupakan isu utama yang menjadi perhatian karena telah menjadi bagian dari kehidupan karyawan dan sulit untuk menghindari stres dari pekerjaan (Parvaiz et al., 2015). Stres merupakan sebuah kondisi dimana seseorang dihadapkan pada konfrontasi antara kesempatan, hambatan, atau permintaan akan apa yang dia inginkan dan hasilnya dipersepsikan tidak pasti dan penting (Noviansyah \& Zunaidah, 2011). Menurut (Jamal, 2011), stres kerja merupakan 
karakteristik lingkungan kerja yang dirasa mengancam secara emosi dan fisik oleh karyawan.

\section{METODE PENELITIAN}

Lokasi penelitian ini adalah pada UPT. Monumen Perjuangan Rakyat Bali yang beralamat jalan Raya Puputan Renon. Alasan peneliti melakukan penelitian di UPT. Monumen Perjuangan Rakyat Bali karena terdapat masalah yang berkaitan dengan komitmen organisasional, stress kerja, dan kepuasan kerja.

Populasi yang digunakan dalam penelitian ini adalah seluruh pegawai yang bekerja pada UPT. Monumen Perjuangan Rakyat Bali yang berjumlah 49 pegawai (pegawai tetap dan pegawai kontrak), sebagai berikut:

Tabel 2.

Data Pegawai UPT. Monumen Perjuangan Rakyat Bali 2018

\begin{tabular}{clc}
\hline No & \multicolumn{1}{c}{ Bagian } & $\begin{array}{c}\text { Jumlah Karyawan } \\
\text { (Orang) }\end{array}$ \\
\hline 1 & Kepala UPT. & 1 \\
2 & KASUBAG. TU. & 1 \\
3 & KASI. Informasi & 1 \\
4 & KASI. Penelitian & 1 \\
5 & Staf Bagian TU & 15 \\
6 & Staf Bagian Informasi & 12 \\
7 & Staf Bagian Penelitian & 9 \\
8 & Tenaga Keamanan & 9 \\
& Total & 49 \\
\hline
\end{tabular}

Sumber: Tata Usaha UPT Monumen Perjuangan Rakyat Bali, 2019

Metode penentuan sampel yang digunakan dalam penelitian ini adalah sampel jenuh karena keseluruhan anggota populasi dijadikan sebagai sampel. Sampel jenuh adalah teknik penentuan sampel apabila jumlah populasi relatif kecil atau kurang dari 100 orang. Berdasarkan uraian diatas besarnya sampel yang diteliti berjumlah 49 orang.

Teknik analisis data yang digunakan dalam penelitian ini adalah analisis jalur (Path Analysis).

Persamaan Sub-struktural 1

$$
\mathrm{Y}_{1}=\beta_{2} \mathrm{X}+\mathrm{e}_{1}
$$

Persamaan Sub-struktural 2

$$
\mathrm{Y}=\beta_{1} \mathrm{X}+\beta_{3} \mathrm{M}+\mathrm{e}_{2}
$$

Keterangan :

$$
\begin{array}{ll}
\mathrm{Y} & =\text { Komitmen organisasi } \\
\mathrm{X} & =\text { Stres kerja } \\
\mathrm{M} & =\text { Kepuasan kerja } \\
\beta_{1}, \beta_{2}, \beta_{3} & =\text { koefisien regresi variabel } \\
\mathrm{e} & =\text { error }
\end{array}
$$




\section{HASIL DAN PEMBAHASAN}

Uji validitas bertujuan untuk memeriksa apakah kuesioner sebagai instrumen penelitian sudah tepat untuk mengukur apa yang seharusnya diukur. Suatu instrumen dikatakan valid apabila memiliki koefisien korelasi antara butir dengan skor total dalam instrumen tersebut lebih besar dari 0,30 dengan tingkat kesalahan Alpha 0,05. Tabel 3 berikut menyajikan hasil uji validitas instrumen penelitian.

Tabel 3.

Rekapitulasi Hasil Uji Validitas Instrumen Penelitian

\begin{tabular}{ccccc}
\hline Variabel & Indikator & $\begin{array}{c}\text { Koefisien } \\
\text { Korelasi }\end{array}$ & Sig. (2-tailed) & Keterangan \\
\hline \multirow{6}{*}{ Komitmen Organisasional(Y) } & Y1 & 0,704 & 0,000 & Valid \\
& Y2 & 0,726 & 0,000 & Valid \\
& Y3 & 0,852 & 0,000 & Valid \\
& Y4 & 0,721 & 0,000 & Valid \\
& Y5 & 0,758 & 0,000 & Valid \\
& Y6 & 0,840 & 0,000 & Valid \\
& Y7 & 0,691 & 0,000 & Valid \\
& Y8 & 0,775 & 0,000 & Valid \\
X1 & 0,805 & 0,000 & Valid \\
& X2 & 0,875 & 0,000 & Valid \\
& X3 & 0,852 & 0,000 & Valid \\
& X4 & 0,786 & 0,000 & Valid \\
Kepuasan Kerja (M) & X5 & 0,898 & 0,000 & Valid \\
& X6 & & 0,000 & Valid \\
& X1 & 0,784 & 0,000 & Valid \\
& X2 & 0,736 & 0,000 & Valid \\
& X3 & 0,803 & 0,000 & Valid \\
& X4 & 0,731 & 0,000 & Valid \\
& X5 & 0,814 & 0,000 & Valid \\
\hline
\end{tabular}

Sumber: Data diolah, 2019

Hasil uji validitas pada Tabel 3. menunjukkan bahwa seluruh instrumen penelitian yang digunakan untuk mengukur variabel komitmen organisasional, stress kerja dan kepuasan kerja memiliki nilai koefisien korelasi dengan skor total seluruh item pernyataan lebih besar dari 0,30 dengan signifikansi kurang dari 0,05. Hal ini menunjukkan bahwa butir-butir pernyataan dalam instrumen penelitian tersebut valid dan layak digunakan sebagai instrumen penelitian.

Tabel 4.

Rekapitulasi Hasil Uji Reliabilitas Instrumen Penelitian

\begin{tabular}{clcc}
\hline No & \multicolumn{1}{c}{ Variabel } & $\begin{array}{c}\text { Cronbadh's } \\
\text { Alpha }\end{array}$ & Keterangan \\
\hline 1. & Komitmen Organisasional $(\mathrm{Y})$ & 0,907 & Reliabel \\
2. & Stres Kerja (X) & 0,920 & Reliabel \\
3. & Kepuasan Kerja $(\mathrm{M})$ & 0,831 & Reliabel \\
\hline \multicolumn{2}{l}{ Sumber: Data diolah, 2019} &
\end{tabular}

Tabel 4. menunjukan bahwa masing-masing nilai cronbach's alpha pada tiap instrumen penelitian lebih besar dari 0,6 (cronbach's alpha > 0,6). Dengan ini 
demikian hasil tersebut menunjukan bahwa semua instrumen terbukti reliabel, sehingga dapat digunakan untuk melakukan penelitian.

Uji normalitas bertujuan untuk mengetahui apakah residual dari model regresi yang dibuat berdistribusi normal atau tidak. Untuk menguji apakah data yang digunakan normal atau tidak dapat dilakukan dengan menggunakan uji Kolmogorov Sminarnov. Apabila koefisien Asymp. Sig. (2-tailed) lebih besar dari 0,05 maka data tersebut dikatakan berdistribusi normal.

Tabel 5.

Uji Normalitas Struktur 1

\begin{tabular}{lc}
\hline & Unstandardized Residual \\
\hline $\mathrm{N}$ & 49 \\
Kolmogorov-Smirnov $\mathrm{Z}$ & 0,835 \\
Asymp.Sig.(2-tailed) & 0,488 \\
\hline Sumber: Data diolah, 2019 &
\end{tabular}

Sumber: Data diolah, 2019

Berdasarkan Tabel 5. dapat dilihat bahwa nilai Kolmogorov Sminarnov (K-S) sebesar 0,835, sedangkan nilai Asymp. Sig. (2-tailed) sebesar 0,488. Hasil tersebut mengindikasikan bahwa model persamaan regresi tersebut berdistribusi normal karena nilai Asymp. Sig. (2-tailed) lebih besar dari nilai alpha 0,05.

Tabel 6.

Uji Normalitas Struktur 2

\begin{tabular}{lc}
\hline & Unstandardized Residual \\
\hline $\mathrm{N}$ & 49 \\
Kolmogorov-Smirnov $Z$ & 0,835 \\
Asymp.Sig.(2-tailed) & 0,489 \\
\hline Sumber: Data diolah, 2019 &
\end{tabular}

Berdasarkan Tabel 6. dapat dilihat bahwa nilai Kolmogorov Sminarnov (KS) sebesar 0,835, sedangkan nilai Asymp. Sig. (2-tailed) sebesar 0,489. Hasil tersebut mengindikasikan bahwa model persamaan regresi tersebut berdistribusi normal karena nilai Asymp. Sig. (2-tailed) lebih besar dari nilai alpha 0,05.

Uji multikolinearitas bertujuan untuk menguji apakah pada model regresi ditemukan adanya korelasi antar variabel bebas. Adanya multikolinearitas dapat dilihat dari nilai tolerance atau variance inflation factor (VIF). Jika nilai tolerance lebih dari 10 persen atau VIF Kurang dari 10, maka dikatakan tidak ada multikolinearitas.

Tabel 7.

Hasil Uji Multikolinearitas

\begin{tabular}{lccc}
\hline & Variabel & Tolerance & VIF \\
\hline Stress Kerja & 0,661 & 1,513 \\
Kepuasan Kerja & 0,661 & 1,513 \\
\hline
\end{tabular}

Sumber: Data diolah, 2019

Berdasarkan Tabel 7. dapat dilihat bahwa nilai tolerance dan VIF dari variabel stress kerja dan kepuasan kerja menunjukkan nilai tolerance untuk setiap 
variabel lebih besar dari 10 persen dan nilai VIF lebih kecil dari 10 yang berarti model persamaan regresi bebas dari multikolinearitas.

Uji heteroskedastisitas bertujuan untuk mengetahui apakah dalam model regresi terjadi ketidaksamaan varians dari residual satu pengamatan ke pengamatan yang lain dan pengujian ini dilakukan dengan uji Glejser. Jika nilai signifikansinya di atas 0,05 maka tidak mengandung gejala heteroskedastisitas.

Tabel 8.

Hasil Uji Heteroskedastisitas Struktur 1

\begin{tabular}{|c|c|c|c|c|c|}
\hline \multirow[b]{2}{*}{ Model } & \multicolumn{2}{|c|}{$\begin{array}{l}\text { Unstandardized } \\
\text { Coefficients }\end{array}$} & \multirow{2}{*}{$\begin{array}{c}\text { Standardized } \\
\text { Coefficients } \\
\text { Beta } \\
\end{array}$} & \multirow[b]{2}{*}{$\mathbf{t}$} & \multirow[b]{2}{*}{ Sig. } \\
\hline & & $\begin{array}{l}\text { Std. } \\
\text { Error }\end{array}$ & & & \\
\hline 1 (Constant) & 0,129 & 0,179 & & 0,718 & 0.476 \\
\hline Stress kerja & 0,63 & 0.047 & 0,194 & 1,359 & 0.181 \\
\hline
\end{tabular}

Sumber: Data diolah, 2019

Pada Tabel 8. dapat dilihat bahwa nilai signifikansi dari variabel stress kerja tersebut lebih besar dari 0,05 yang berarti tidak terdapat pengaruh antara variabel bebas terhadap absolute residual. Dengan demikian, model yang dibuat tidak mengandung gejala heteroskedastisitas.

Tabel 9.

Hasil Uji Heteroskedastisitas Struktur 2

\begin{tabular}{|c|c|c|c|c|c|}
\hline \multirow[b]{2}{*}{ Model } & \multicolumn{2}{|c|}{$\begin{array}{c}\text { Unstandardized } \\
\text { Coefficients } \\
\text { Std. }\end{array}$} & \multirow{2}{*}{$\begin{array}{c}\text { Standardized } \\
\text { Coefficients } \\
\text { Beta } \\
\end{array}$} & \multirow[b]{2}{*}{$\mathbf{t}$} & \multirow[b]{2}{*}{ Sig. } \\
\hline & B & Error & & & \\
\hline 1 (Constant) & 0,042 & 0,490 & & 0,085 & 0.933 \\
\hline Stress kerja & 0.025 & 0.056 & 0.082 & 0.453 & 0.653 \\
\hline Kepuasan kerja & 0,031 & 0.082 & 0,068 & 0,377 & 0.708 \\
\hline
\end{tabular}

Sumber: Data diolah, 2019

Pada Tabel 9. dapat dilihat bahwa nilai signifikansi dari variabel stress kerja, dan kepuasan kerja masing-masing sebesar 0,025 dan 0,031. Nilai tersebut lebih besar dari 0,05 yang berarti tidak terdapat pengaruh antara variabel bebas terhadap absolute residual. Dengan demikian, model yang dibuat tidak mengandung gejala heteroskedastisitas.

Tabel 10.

Hasil Analisis Jalur Persamaan Regresi 1

\begin{tabular}{lccccc}
\hline Model & $\begin{array}{c}\text { Unstandardized } \\
\text { Coefficients } \\
\text { B }\end{array}$ & Std. Error & $\begin{array}{c}\text { Standardized } \\
\text { Coefficients } \\
\text { Beta }\end{array}$ & T & Sig. \\
\hline 1 (Constant) & 5,597 & 0,312 & & 17,917 & 0,000 \\
Stress Kerja & $-0,399$ & 0,081 & $-0,582$ & $-4,909$ & 0,000 \\
& & & & Sig F: & \\
$\mathrm{R}^{2}: 0,325$ & F Statistik: & & 0,000 & \\
& & 24,101 & &
\end{tabular}

Sumber: Data diolah, 2019 
Persamaan Sub-struktural 1

$$
\begin{aligned}
& Y_{1}=\beta_{2} X+e_{1} \\
& Y_{1}=-0,582 X+e_{1}
\end{aligned}
$$

Tabel 11.

\begin{tabular}{|c|c|c|c|c|c|}
\hline Model & $\begin{array}{c}\text { Unstandardized } \\
\text { Coefficients } \\
\text { B } \\
\end{array}$ & Std. Error & $\begin{array}{c}\text { Standardized } \\
\text { Coefficients } \\
\text { Beta }\end{array}$ & $\mathbf{T}$ & Sig. \\
\hline 1 (Constant) & 2,670 & 0,712 & & 3,750 & 0,000 \\
\hline Stress Kerja & $-0,291$ & 0,082 & $-0,379$ & $-3,576$ & 0,001 \\
\hline Kepuasan & 0,595 & 0,119 & 0,530 & 5,005 & 0,000 \\
\hline $\mathrm{R}^{2}: 0,644$ & & $\begin{array}{c}\text { F Statistik: } \\
44,380\end{array}$ & & $\begin{array}{l}\text { Sig F: } \\
0,000\end{array}$ & \\
\hline
\end{tabular}
Hasil Analisis Jalur Persamaan Regresi 2

Sumber: Data diolah, 2019

Persamaan Sub-struktural 2

$$
\mathrm{Y}=-0,379 \mathrm{X}+0,530 \mathrm{M}+\mathrm{e} 2
$$

Keterangan :

$$
\begin{array}{ll}
\mathrm{Y} & =\text { Komitmen organisasi } \\
\mathrm{X} & =\text { Stres kerja } \\
\mathrm{M} & =\text { Kepuasan kerja } \\
\beta_{1}, \beta_{2}, \beta_{3} & =\text { koefisien regresi variabel } \\
\mathrm{e} & =\text { error }
\end{array}
$$

(1) Pengaruh langsung (direct effect)

Pengaruh variabel stress kerja $(\mathrm{X})$ terhadap komitmen organisasi $(\mathrm{Y})$ :

$$
\beta_{2}=-0,379
$$

Pengaruh variabel stress kerja $(\mathrm{X})$ terhadap kepuasan kerja $(\mathrm{M})$ :

$$
\beta_{1}=-0,382
$$

Pengaruh variabel kepuasan kerja $(\mathrm{M})$ terhadap komitmen organisasi (Y) :

$$
\beta_{3}=0,350
$$

Pengaruh variabel stress kerjs (X) terhadap komitmen organisasi (Y) dengan kepuasan kerja (M) sebagai variabel perantara:

$$
\begin{aligned}
& Y=-0,382 \times 0,350 \\
& Y=-0,1337
\end{aligned}
$$

Total pengaruh variabel $\mathrm{X}$ terhadap $\mathrm{Y}$ melalui $\mathrm{M}$ dirumuskan sebagai berikut :

$$
\begin{aligned}
& Y=-0,379+(-0,1337) \\
& Y=-0,5127
\end{aligned}
$$

Menguji nilai koefisien determinasi $\left(\mathrm{R}^{2}\right)$ dan standard error (e)

$$
\begin{aligned}
& \mathrm{e}_{1}=\sqrt{1-} 0,325 \\
& =0,821 \\
& \mathrm{e}_{2}=\sqrt{1-} 0,644 \\
& =0,596
\end{aligned}
$$

Standard error telah dihitung, maka didapatkan hasil pengaruh error 1 sebesar 0,821 dan pengaruh error 2 sebesar 0,596 . Perhitungan nilai koefisien determinasi total adalah sebagai berikut: 


$$
\begin{aligned}
\mathrm{R}^{2} \mathrm{~m} & =1-(0,821)^{2}(0,596)^{2} \\
& =1-(0,674)(0,355) \\
& =1-0,239 \\
& =0,761
\end{aligned}
$$

Nilai koefisien determinasi total sebesar 0,761 yang berarti bahwa sebesar 76,1 persen variasi komitmen organisasional dipengaruhi oleh stress kerja dan kepuasan kerja sedangkan sisanya sebesar 23,9 persen dijelaskan oleh faktor lain yang tidak dimasukkan ke dalam model.

Hasil pengujian pada Tabel 11. diperoleh nilai koefisien signifikan $0,000 \leq$ 0,05. Hasil tersebut menunjukan bahwa stress kerja dan kepuasan kerja berpengaruh secara simultan dan signifikan terhadap komitmen organisasional.

Hasil analisis pengaruh likuiditas terhadap profitabilitas pada Tabel 10. diperoleh nilai koefisien beta sebesar -0,582 dengan nilai signifikan t $0,000<$ 0,05 , sehingga $\mathrm{H}_{0}$ ditolak dan $\mathrm{H}_{1}$ diterima. Hasil tersebut menunjukan bahwa stress kerja berpengaruh negatif dan signifikan terhadap kepuasan kerja

Hasil analisis pengaruh likuiditas terhadap profitabilitas pada Tabel 11. iperoleh nilai koefisien beta sebesar 0,530 dengan nilai signifikan t $0,000<0,05$, sehingga $\mathrm{H}_{0}$ ditolak dan $\mathrm{H}_{2}$ diterima. Hasil tersebut menunjukan bahwa kepuasan kerja berpengaruh positif dan signifikan terhadap komitmen organisasional,

Hasil analisis pengaruh likuiditas terhadap profitabilitas pada Tabel 11. diperoleh nilai koefisien beta sebesar -0,379 dengan nilai signifikan t 0,001 <

\begin{tabular}{|c|c|c|c|}
\hline \multicolumn{4}{|c|}{$\begin{array}{l}\text { Pengaruh Langsung, Pengaruh Tidak Langsung serta Pengaruh Total Stress } \\
\text { Kerja }\left(\mathbf{X}_{1}\right) \text {, Kepuasan Kerja }(\mathbf{M}) \text { dan Komitmen Organisasional }\left(\mathbf{Y}_{2}\right)\end{array}$} \\
\hline $\begin{array}{l}\text { Pengaruh } \\
\text { Variabel }\end{array}$ & $\begin{array}{l}\text { Pengaruh } \\
\text { Langsung }\end{array}$ & $\begin{array}{l}\text { Pengaruh tidak langsung melalui } \\
\text { kepuasan kerja }\end{array}$ & $\begin{array}{l}\text { Pengaruh } \\
\text { Total }\end{array}$ \\
\hline $\mathrm{X} \rightarrow \mathrm{M}$ & $-0,382$ & - & $-0,382$ \\
\hline $\mathrm{X} \rightarrow \mathrm{Y}$ & $-0,379$ & $-0,1337$ & $-0,5127$ \\
\hline $\mathrm{M} \rightarrow \mathrm{Y}$ & 0,350 & - & 0,350 \\
\hline
\end{tabular}
0,05, sehingga $\mathrm{H}_{0}$ ditolak dan $\mathrm{H}_{3}$ diterima. Hasil tersebut menunjukan bahwa stress kerja berpengaruh negatif dan signifikan terhadap komitmen organisasional.

Tabel 12.

Sumber: Data diolah, 2019

Hasil pada Tabel 12. menunjukkan pengaruh langsung stress kerja terhadap komitmen organisasional sebesar -0,379, sedangkan pengaruh tidak langsung yang dimediasi oleh kepuasan kerja menunjukkan nilai koefisien beta sebesar -0,1337. Hasil tersebut membuktikan bahwa kepuasan kerja mampu memediasi pengaruh stress kerja terhadap komitmen organisasional dengan pengaruh total yang diperoleh sebesar $-0,5127$.

Uji sobel dilakukan untuk menguji pengaruh tidak langsung variabel stress kerja (X1) dan terhadap komitmen organisasional (Y) melalui kepuasan kerja (M). Uji sobel dihitung dengan menggunakan aplikasi Microsoft Excel 2010. Tahapan dalam pengujian pengaruh tidak langsung dengan uji sobel yaitu sebagai berikut. 


$$
\begin{aligned}
& Z=\frac{(-0,399)(0,595)}{\sqrt{(-0,399)^{2}(0,119)^{2}+(0,595)^{2}(0,081)^{2}+(0,081)^{2}(0,119)^{2}}} \\
& Z=\frac{0,237405}{\sqrt{0,002226+0,002124+0,0000084}} \\
& Z=\frac{-0,237405}{0,0043584} \\
& Z=54,47
\end{aligned}
$$

Berdasarkan hasil uji sobel dalam penelitian ini menunjukkan bahwa hasil tabulasi $\mathrm{Z}=54,47>1,96$. Hasil tersebut memiliki arti bahwa kepuasan kerja mampu memediasi pengaruh stress kerja terhadap komitmen organisasional.

Berdasarkan hasil analisis nilai koefisien beta sebesar -0,582 dengan nilai signifikan $\mathrm{t} 0,000<0,05$, sehingga $\mathrm{H}_{0}$ ditolak dan $\mathrm{H}_{1}$ diterima. Hasil tersebut menunjukan bahwa stress kerja berpengaruh negatif dan signifikan terhadap kepuasan kerja, dimana semakin rendah stress kerja pada pegawai UPT. Monumen Perjuangan Rakyat Bali maka akan semakin tinggi kepuasan kerja pegawai.

Penelitian ini mendukung beberapa hasil penelitian sebelumnya yang dilakukan oleh (Fadhilah, 2010) menunjukkan bahwa semakin tinggi stress kerja yang dirasakan oleh karyawan, maka kepuasan kerja karyawan akan menurun atau sebaliknya, semakin rendah stress kerja maka semakin tinggi kepuasan kerja karyawan. Stres kerja memiliki pengaruh negatif yang signifikan terhadap kepuasan kerja, hal ini bermakna stres kerja yang dialami karyawan dapat mempengaruhi apa yang mereka rasakan baik itu menyangkut pekerjaan maupun hasil yang mereka terima (Wibowo et al., 2015).

Berdasarkan hasil analisis pengaruh kepuasan kerja terhadap komitmen organisasional diperoleh nilai signifikansi sebesar 0,530 dengan nilai signifikan $\mathrm{t}$ $0,000<0,05$, sehingga $\mathrm{H}_{0}$ ditolak dan $\mathrm{H}_{2}$ diterima. Hasil tersebut menunjukan bahwa kepuasan kerja berpengaruh positif dan signifikan terhadap komitmen organisasional pada UPT. Monumen Perjuangan Rakyat Bali. Hal ini memiliki makna bahwa pegawai yang merasa puas dengan pekerjaannya biasanya memiliki komitmen organisasional yang tinggi.

Penelitian ini mendukung beberapa hasil penelitian sebelumnya yang dilakukan oleh (Kartikarini, 2015) mengatakan bahwa kepuasan kerja memiliki keterkaitan positif terhadap komitmen organisasi. Begitu juga dengan (Eslami \& Gharakhani, 2012) yang menyatakan karyawan yang memiliki kepuasan kerja cenderung berkomitmen untuk organisasi dan karyawan yang puas dan berkomitmen lebih mungkin untuk menghadiri pekerjaan. (Lumley et al., 2011) menyimpulkan kepuasan kerja mempengaruhi sikap masyarakat terhadap pekerjaan dan berbagai aspek pekerjaan mereka, kepuasan kerja dipengaruhi oleh pribadi yang menyebabkan reaksi emosional yang mempengaruhi komitmen organisasi.

Hasil pengujian hipotesis pengaruh stress kerja terhadap komitmen organisasional diperoleh nilai signifikansi sebesar $-0,379$ dengan nilai signifikan $\mathrm{t}$ $0,001<0,05$, sehingga $\mathrm{H}_{0}$ ditolak dan $\mathrm{H}_{3}$ diterima. Hasil tersebut menunjukan 
bahwa stress kerja berpengaruh negatif dan signifikan terhadap komitmen organisasional UPT. Monumen Perjuangan Rakyat Bali Hal ini memiliki makna bahwa seorang pegawai yang merasakan stres kerja yang tinggi tidak memiliki komitmen terhadap perusahaan .

Hasil penelitian ini mendukung temuan dari (Velnampy \& Aravinthan, 2013) yang menyatakan adanya hubungan negatif antara stres kerja dan komitmen organisasi. Stres kerja berpengaruh negatif pada komitmen organisasi karena semakin tinggi stres mengakibatkan semakin menurunnya komitmen organisasi (Iresa et al., 2015). Penelitian yang dilakukan (Cha et al., 2016) dalam penelitiannya mengungkapkan stres kerja memiliki hubungan yang negatif dan signifikan dengan komitmen organisasional.

Hasil uji menunjukan bahwa nilai $\mathrm{Z}$ hitung sebesar uji sobel dalam penelitian ini menunjukkan bahwa hasil tabulasi $\mathrm{Z}=54,47>1,96$. Hasil tersebut memiliki arti bahwa kepuasan kerja mampu memediasi pengaruh stress kerja terhadap komitmen organisasional UPT. Monumen Perjuangan Rakyat Bali. Hal ini memiliki makna bahwa stres kerja mampu mempengaruhi komitmen organisasional secara langsung maupun tidak langsung, pengaruh tidak langsung stres kerja terhadap komitmen organisasional melalui kepuasan kerja.

Penelitian ini mendukung beberapa hasil penelitian sebelumnya yang dilakukan oleh (Christama, 2011), menunjukan bahwa kepuasan kerja mampu memediasi peran stres kerja terhadap komitmen organisasi pada caddy PT. Golf Graha Family Surabaya. Selain itu, menurut (Kasanah, 2007), menunjukkan ada pengaruh positif secara tidak langsung yang signifikan antara stres terkait tantangan dengan komitmen organisasi melalui kepuasan kerja. (Yousef, 2002), menyatakan bahwa terdapat hubungan yang signifikan antara kepuasan kerja dan komitmen organisasional yang dapat memperkuat pengaruh antara stress kerja terhadap komitmen organisasional.

Implikasi hasil penelitian ini memfokuskan pada kegunaan dan manfaat dari hasil penelitian untuk meningkatkan komitmen organisasional pada pegawai UPT. Monumen Perjuangan Rakyat Bali. Implikasi pertama yaitu diperoleh hasil bahwa pegawai UPT. Monumen Perjuangan Rakyat memiliki tingkat stres kerja yang cukup rendah, hal ini disebabkan karena pegawai dapat menghabiskan lebih banyak waktu dengan keluarga dibandingkan waktu bekerja.

Implikasi yang kedua yaitu diperoleh hasil bahwa tingginya kepuasan kerja pada pegawai UPT. Monumen Perjuangan Rakyat Bali karena pegawai merasa puas atas promosi yang didapatkan atas pekerjaan yang dilakukan, promosi sangat penting bagi pegawai karena mampu membuat pegawai lebih semangat dalam bekerja

Implikasi yang ketiga yaitu diperoleh hasil bahwa tingginy(Karwati \& Priansa, 2014) komitmen organisasional pada pegawai UPT. Monumen Perjuangan Rakyat Bali, hal ini dapat dilihat dari banyaknya pegawai yang merasa sedikit memiliki pilihan jika meninggalkan perusahaan.

Implikasi teoritis yang diperoleh dari penelitian ini adalah stres kerja dan kepuasan kerja secara positif dan signifikan mempengaruhi komitmen organisasional. Kepuasan kerja merupakan variabel mediasi karena mampu menunjukkan bahwa stress kerja dan kepuasan kerja sebagai faktor - faktor yang 
mempengaruhi komitmen organisasional. Hasil penelitian ini memberi dukungan empiris dan dinyatakan dapat memperkuat hasil-hasil studi terdahulu. Bagi pihak perusahaan penelitian ini dapat digunakan untuk pengambilan keputusan dan tindakan perbaikan saat perusahaan mengalami masalah.

Berdasarkan penelitian yang telah dilakukan, terdapat beberapa keterbatasan dalam penelitian ini, yaitu: penelitian ini dilakukan hanya sebatas pada ruang lingkup perusahaan UPT. Monumen Perjuangan Rakyat Bali sehingga hasil penelitian ini tidak dapat digunakan pada perusahaan lain dalam sektor lainnya. Faktor-faktor yang mempengaruhi komitmen organisasional dalam penelitian ini adalah stress kerja dan kepuasan kerja, sedangkan masih banyak faktor lain yang dapat mempengaruhi. Mengingat penelitian ini dilakukan dalam titik waktu tertantu sedangkan lingkungan setiap saat bisa berubah, yang menyebabkan penelitian ini penting untuk dilakukan kembali. Masih kurangnya kejujuran responden dalam menjawab kuesioner. Pengembalian kueisioner memerlukan waktu yang cukup lama.

\section{SIMPULAN}

Stress kerja berpengaruh negatif dan signifikan terhadap kepuasan kerja, dimana semakin rendah stress kerja pada pegawai UPT. Monumen Perjuangan Rakyat Bali maka akan semakin tinggi kepuasan kerja pegawai. Kepuasan kerja berpengaruh positif dan signifikan terhadap komitmen organisasional pada UPT. Monumen Perjuangan Rakyat Bali. Hal ini memiliki makna bahwa pegawai yang merasa puas dengan pekerjaannya biasanya memiliki komitmen organisasional yang tinggi. Stress kerja berpengaruh negatif dan signifikan terhadap komitmen organisasional UPT. Monumen Perjuangan Rakyat Bali Hal ini memiliki makna bahwa seorang pegawai yang merasakan stres kerja yang tinggi tidak memiliki komitmen terhadap perusahaan. Kepuasan kerja mampu memediasi pengaruh stress kerja terhadap komitmen organisasional UPT. Monumen Perjuangan Rakyat Bali. Hal ini memiliki makna bahwa stres kerja mampu mempengaruhi komitmen organisasional secara langsung maupun tidak langsung, pengaruh tidak langsung stres kerja terhadap komitmen organisasional melalui kepuasan kerja. Untuk meningkatkan komitmen organisasional pada pegawai, perusahaan harus mampu membuat pegawainya merasa kehidupannya akan terganggu apabila meninggalkan perusahaan, dan harus mampu membuat pegawainya bersedia dilibatkan dalam kegiatan kerja demi kepentingan perusahaan dengan cara memberikan gaji yang cukup, tujangan-tunjangan, dan hubungan yang baik antar pegawai sehingga pegawai merasa ingin bertahan dalam perusahaan. Upaya mengurangi stres kerja pada pegawai UPT. Monumen Perjuangan Rakyat Bali hendaknya mampu membuat pegawainya melakukan pekerjaan yang sesuai dengan keterampilan yang dimiliki dengan cara mengetahui kemampuan yang dimiliki oleh pegawainya sehingga tugas-tugas yang diberikan sesuai. Meningkatkan kepuasan kerja seharusnya atasan mampu memperlakukan pegawainya secara adil dengan cara memberikan tugas-tugas yang sesuai, dan memberikan timbal balik yang sesuai dengan pekerjaan yang dilakukan. 


\section{REFERENSI}

Afrizal, P. R., Musadieq, M. Al, \& Ruhana, I. (2014). Pengaruh konflik kerja dan stres kerja terhadap kepuasan kerja (Studi PAda Karyawan PT. TASPEN (Persero) Cabang MAlang). Jurnal Administrasi Bisnis (JAB), 8(1), 1-10.

Ali, A. (2009). The Role of Leadership in Human Resource Management a Comparative Study of Specific Public and Private Sectors in Pakistan. Journal of Management and Social Sciences, 5(2), 180-194.

Bokti, N. L. M., \& Talib, M. A. (2009). A Preliminary Study on Occupational Stress and Job Satisfaction among Male Navy Personnel at a Naval Base in Lumut, Malaysia. Journal of International Social Reasearch, 2(9), 300-307.

Cha, J. M., Kim, S. H., \& Cichy, R. F. (2016). Job Satisfaction , Organizational Commitment, and Contextual Performance : Examining Effects of Work Status and Emotional Intelligence among Private Club Staff Members. Psychology and Marketing, 21(6), 405-424.

Chaudhry, A. Q. (2012). The Relationship between Occupational Stress and Job Satisfaction: The Case of Pakistani Universities. International Education Studies, 5(3), 212-221. https://doi.org/10.5539/ies.v5n3p212

Christama, D. (2011). Analisis Pengaruh Stres Peran Terhadap Sebagai Variabel Mediator Pada Caddy Pt Golf Graha Famili Surabaya Diajukan. Universitas Airlangga.

Dewi, N. P. E. L., \& Netra, I. G. S. K. (2015). Pengaruh Stres Kerja dan MOtivasi Kerja Terhadap Kepuasan Kerja Karyawan pada Matahari Bungalow Restourant and SPA Legian Kuta-Bali. E-Jurnal Manajemen Unud, 4(7), 1933-1948.

Dhania, D. R. (2010). Pengaruh Stres Kerja , Beban Kerja (Studi Pada Medical Representatif Di Kota Kudus). Jurnal Psikologi, 1(1), 15-23.

Eslami, J., \& Gharakhani, D. (2012). Organizational Commitment and Job Satisfaction. Journal of Science and Technology, 2(2), 85-91.

Fadhilah, M. L. (2010). Analisis Pengaruh Stres Kerja Terhadap Kepuasan Kerja dengan Dukungan Sosial Sebagai variabel Moderating. Universitas Diponegoro.

Gunlu, E., Aksarayli, M., \& Perçin, N. Ş. (2010). Job satisfaction and organizational commitment of hotel managers in Turkey. Journal of Contemporary Hospitality Management, 22(5), 693-717. https://doi.org/10.1108/09596111011053819

Handoko, T. H. (2012). Manajemen Personalia dan Sumber Daya Manusia (2nd ed.). Yogyakarta: BPFE.

Harun, H., Salleh, R., Memon, M. A., Baharom, M. N. R., \& Abdullah, A. (2017). Job Satisfaction, Organizational Commitment and Stress among Offshore 
Oil and Gas Platform Employees. Asian Social Science, 10(11), 28-32. https://doi.org/10.5539/ass.v10n11p28

Hassan, A. (2002). Organizational Justice As A Determinant Of Organizational Commitment, 7(2), 55-66.

Iqbal, S., Ehsan, S., Rizwan, M., \& Noreen, M. (2014). The impact of organizational commitment, job satisfaction, job stress and leadership support on turnover intention in educational institutes. Journal of Human Resource Studies, 4(2), 181-195.

Irawati, R., \& Liana, Y. (2013). ISSN No . 1978-6034 Effect of Transformational Leadership Style and Job Satisfaction on Employee Performance With Organizational Commitment As Interval Variables Pengaruh Gaya Kepemimpinan Transformasional dan Kepuasan Kerja terhadap Kinerja Karyawan deng. ESAI, 7(3).

Iresa, A. R., Utami, H. N., \& Prasetya, A. (2015). Organisasional Dan Kinerja Karyawan (Studi pada Karyawan PT . Telekomunikasi Indonesia , Tbk Witel Malang). Jurnal Administrasi Bisnis (JAB), 23(1), 1-10.

Jamal, M. (2011). Job Stress , Job Performance and Organizational Commitment in a Multinational Company: An Empirical Study in two Countries, 2(20), 20-29.

Karim, F., \& Rehman, O. (2012). Impact of Job Satisfaction , Perceived Organizational Justice and Employee Empowerment on Organizational Commitment in Semi- Government Organizations of Pakistan. Journal of Business Studies, 3(4), 92-104.

Kartikarini, M. (2015). Pengaruh Servant Leadership Dan Kepuasan Kerja Terhadap Organizational Citizenship Behaviour Karyawan Hotel Bintang-2 Di Yogyakarta. Universitas Negeri Yogyakarta.

Karwati, E., \& Priansa, D. J. (2014). Manajemen kelas. Bandung: Alfabeta.

Kasanah, W. H. (2007). Pengaruh Stres Kerja Terhadap Komitmen Organisasi Melalui Kepuasan Kerja (Studi Pada Karyawan Hotel Pelangi Malang). Universitas Negeri Malang.

Khatibi, A., Asadi, H., \& Hamidi, M. (2009). The Relationship Between Job Stress and Organizational Commitment in National Olympic and Paralympic Academy. World Jurnal of Sport Sciences, 2(4), 272-278.

Li, L., Hu, H., Zhou, H., He, C., Fan, L., Liu, X., ... Sun, T. (2014). Work stress , work motivation and their effects on job satisfaction in community health workers: a cross-sectional survey in China. Journal BMJ, 10(4), 1-9. https://doi.org/10.1136/bmjopen-2014-004897

Lumley, E. J., Coetzee, M., Tladinyane, R., \& Ferreira, N. (2011). Exploring the job satisfaction and organisational commitment of employees in the 
information technology environment. Journal Human Resource Management, 15(1), 100-118.

Luthans, F. (2008). Organitational Behaviour (Eleventh E). Singapural: Mc Graw Hill.

Maelina Sepa. (2013). Pengaruh Stres Kerja Terhadap Komitmen Organisasi Dan Kepuasan Kerja Sebagai Variabel Intervening Pada Pegawai Wanita Di Kota Pariaman. Universitas Bung Hatta.

Murty, W. A., \& Hudiwinarsih, G. (2012). Pengaruh Kompensasi, Motivasi Dan Komitmen Organisasional Terhadap Kinerja Karyawan Bagian Akuntansi (Studi Kasus Pada Perusahaan Manufaktur Di Surabaya). The Indonesian Accounting Review, 2(2), 215-228.

Noviansyah, \& Zunaidah. (2011). Pengaruh Stres Kerja Dan Motivasi Kerja Terhadap Kinerja Karyawan PT. Perkebunan Minanga Ogan Baturaja. Jurnal Manajememn Bisnis, 9(18), 43-58.

Özer, G., \& Günlük, M. (2010). The effects of discrimination perception and job satisfaction on Turkish public accountants' turnover intention. Journal of Business Management, 4(8), 1500-1509.

Pangat, A. P. O. (2013). Analisis Pengaruh Job Insecurity Terhadap Kepuasan Kerja Terhadap Kinerja Karyawan Outsourcing Pt Upaya Kelola Profitama. Jurnal Ekonomi Dan Bisnis, 23(2), 64-71.

Parvaiz, L., Batool, S., Khalid, A., \& AftabFarooqi, Y. (2015). Impact of Stressors ( Role conflict, Role overload, Leadership Support and Organizational Politics ) on Job Stress and its subsequent impact on Turnover Intention. Journal of Business and Management, 4(10), 52-63.

Priyono, F. M. A. (2012). Pengaruh Gaya Kepemimpinan Terhadap Kepuasan Kerja. Journal of Business and Banking, 2(1), 113-122.

Putri, W. S. I., Rahardjo, K., \& Djudi, M. (2014). Berdasarkan Status Karyawan (Studi Pada Karyawan PT . Kobexindo Tractors Tbk . Representative Office Bengkulu). Jurnal Administrasi Bisnis (JAB), 10(1), 1-7.

Raharjo, S. T., \& Nafisah, D. (2006). Analisis Pengaruh Gaya Kepemimpinan Terhadap Kepuasan Kerja , Komitmen Organisasi (Studi Empiris Pada Departemen Agama Kabupaten Kendal Dan Departemen Agama Kota Semarang). Jurnal Studi Manajemen Dan Organisasi, 3(2), 69-81.

Rismawan, P. A. E., Supartha, W. G., \& Yasa, N. N. K. (2014). Peran Mediasi Komitmen Organisasional Pada Pengaruh Stress Kerja Dan Kepuasan Kerja Terhadap Intensi Keluar Karyawan. E-Jurnal Manajemen Unud, 3(8), 424441.

Soejipto, B. E. (2008). Untuk mengetahui kepuasan kerja sebagai pemediasi pengaruh stress kerja terhadap komitmen organisasional. Kepanjen: PT. 
Octa Mitra Nusa Persada.

Sutrisno, E. (2016). Human resources management human resources. Jakarta: Prenada Media Group, Kencana.

Taurisa, C. M. (2012). Analisis pengaruh budaya organisasi dan kepuasan kerja terhadap komitmen organisasional dalam meningkatkan kinerja karyawan (Stufi Pada PT. Sido Muncul Kaligawe Semarang), (1), 1-16.

Tukimin. (2014). Pengaruh Stres Kerja Terhadap Kepuasan Kerja Pada Dinas Pertanian Sumatera Utara. Jurnal Manajemen Bisnis, 15(1), 4189-4384.

Umar, H. (2014). Riset Sumber Daya Manusia Dalam Organisasi. Jakarta: PT. Gramedia Pustaka Utama.

Velnampy, T., \& Aravinthan, S. A. (2013). Occupational Stress and Organizational Commitment in Private Banks: A Sri Lankan Experience. Journal Management, 5(7), 291.

Wibowo, I. G. P., Riana, G., \& Putra, M. S. (2015). Pengaruh Stres Kerja Terhadap Kepuasan Kerja dan Komitmen Organisasional Karyawan. EJurnal Manajemen Unud, 4(2), 125-145.

Yani, I. M., Supartha, W. G., \& Subudi, M. (2016). Pengaruh Pemberdayaan Dan Kepuasan Kerja Terhadap Komitmen Organisasional Guru Di Smk N 1 Mas Ubud. E-Jurnal Manajemen Unud, 5(12), 4177-4208.

Yousef, D. A. (2002). Job satisfaction as a mediator of the relationship between role stressors and organizational commitment A study from an Arabic cultural perspective. Journal of Magerial Psychology, 17(4), 250-266. https://doi.org/10.1108/02683940210428074

\section{\{Bibliography\}}

